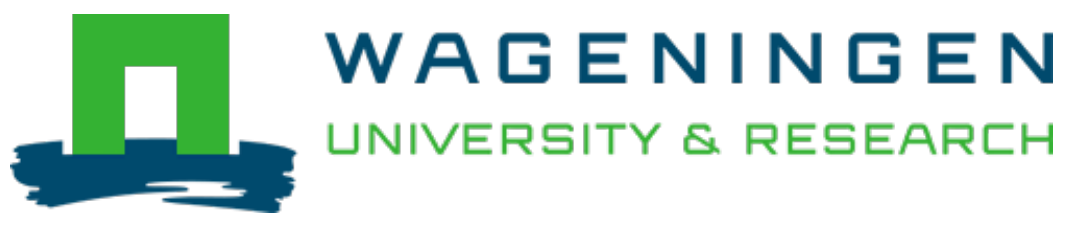

\author{
Room for the river, no room for conflict \\ Split Waters \\ Roth, Dik; Warner, Jeroen; Winnubst, Madelinde \\ https://doi.org/10.4324/9781003030171-5
}

This publication is made publicly available in the institutional repository of Wageningen University and Research, under the terms of article $25 \mathrm{fa}$ of the Dutch Copyright Act, also known as the Amendment Taverne. This has been done with explicit consent by the author.

Article $25 \mathrm{fa}$ states that the author of a short scientific work funded either wholly or partially by Dutch public funds is entitled to make that work publicly available for no consideration following a reasonable period of time after the work was first published, provided that clear reference is made to the source of the first publication of the work.

This publication is distributed under The Association of Universities in the Netherlands (VSNU) 'Article $25 \mathrm{fa}$

implementation' project. In this project research outputs of researchers employed by Dutch Universities that comply with the legal requirements of Article $25 \mathrm{fa}$ of the Dutch Copyright Act are distributed online and free of cost or other barriers in institutional repositories. Research outputs are distributed six months after their first online publication in the original published version and with proper attribution to the source of the original publication.

You are permitted to download and use the publication for personal purposes. All rights remain with the author(s) and / or copyright owner(s) of this work. Any use of the publication or parts of it other than authorised under article $25 \mathrm{fa}$ of the Dutch Copyright act is prohibited. Wageningen University \& Research and the author(s) of this publication shall not be held responsible or liable for any damages resulting from your (re)use of this publication.

For questions regarding the public availability of this publication please contact openscience.library@wur.nl 


\title{
ROOM FOR THE RIVER, NO ROOM FOR CONFLICT
}

\section{Narratives of participation, win-win, consensus, and co-creation in Dutch spatial flood risk management}

\author{
Dik Roth, Jeroen Warner and Madelinde Winnubst
}

\section{Introduction}

The Netherlands, a low-lying deltaic country, shaped historically by the combined influences of the North Sea and the transboundary rivers Rhine, Meuse, Scheldt in the west, and Ems in the north-east, is known worldwide for its flood protection infrastructure. With 17 million people living in a relatively small area $\left(41,543 \mathrm{~km}^{2}\right)$, the country is densely populated, especially the western conurbation, which is also the most industrialised. About 26 per cent of the country lies below sea level, while another 29 per cent is sensitive to flooding (Netherlands Environmental Assessment Agency 2004, 2010). The west is the most flood-sensitive part of the country.

Historically, specific institutional arrangements and practices of flood defence and water control developed through the so-called water boards (waterschappen). Originating in the Middle Ages, for many centuries these were key local water governance institutions. Before 1900, there were an estimated 3,500 water boards. Since then, their number has radically decreased, from around 2,600 in 1950 to the current 21 (see https://dutchwaterauthorities.com; accessed on 28 October 2018). The reduced number of boards and their decreasing importance as local institutions was the consequence of the establishment and growing power of the national water management agency (Rijkswaterstaat) from the late eighteenth century onwards (Toonen, Dijkstra and van der Meer 2006; van Heezik 2008).

Since 1953, when a North Sea storm surge caused more than 1,800 victims in the southwestern part of Netherlands, the Rijkswaterstaat, which had developed into a hierarchically structured organisation, started making serious coastal defence works (the Delta Works programme) and, later, river dike enhancements. However, in the 1960s and the 1970s, interventions for diking along rivers and damming along the coast increasingly led to protests by concerned inhabitants: societal protest heralding the demise of uncontested power and authority through Europe had brought 
about changes in the Dutch water world as well. Concerned citizens, professional groups (fishermen) and nature and environmental NGOs saw their property and values threatened. Claims of professional engineering skills and expertise no longer sufficed to maintain authority and legitimacy for policies, plans and interventions.

In the 1990s, near-floods and a growing awareness of climate change spurred a move away from purely infrastructural flood protection towards combined spatialinfrastructural ones. Simply put, infrastructural flood protection here refers to the practice of diking to confine rivers within their beds, thus also reducing their space. Spatial measures increase the space for the river by, for instance, deepening the river bed, removing obstacles, relocating dikes, creating river bypasses, or preparing special areas for temporary water storage (calamity storage). These new approaches resulted in a policy line called 'Room for the River', which was implemented between 2006 and 2015 (van Stokkom, Smits and Leuven 2005). As 'Room for the River' created new linkages between land and water, making the latter flow rather than confining it and separating it off from human settlement, this policy posed new challenges for interaction with citizens affected by river interventions. In the past, water policies brought technical solutions devised and implemented top-down by the Rijkswaterstaat. There was little awareness of the importance of dealing with societal protest and conflict. This top-down tradition has also influenced the 'Room for the River' programme. Conflicts with citizen groups, caused by the new approaches, often arose because local inhabitants felt excessively or unnecessarily hit by planned interventions (Wolsink 2006; Warner, Edelenbos and van Buuren 2013a; 2013b).

In this chapter, we discuss such conflicts against the background of the shifts from top-down to 'stakeholder' or 'governance' approaches to water management and the accompanying policy narratives. These shifts created new opportunities for citizens to become involved in planning and decision-making as 'stakeholders' (Warner, Edelenbos and van Buuren 2013a). However, the flipside is the depoliticisation of the issues at stake and the co-optation of critical citizens incorporated into 'sounding-board groups' (klankbordgroep) or similar arrangements for orchestrated participation. Thus, conflicts over water interventions tend to be 'managed' and concealed rather than faced and dealt with.

To illustrate this, we use a historical approach, in which we discuss and compare experiences with three spatial-infrastructural interventions for flood risk management in the last two decades: the first, during the transition towards spatial policies that intensified water-land interactions; the second under the 'Room for the River' programme; and the third in the post-Room for the River period, under the recently developed Delta programme. Each of these programmes has a specific narrative which can be explained as 'making meaning' (Abma 1999: 12). Narratives may be ideological, prescribing how the world should be viewed. In other words, by narratives we mean an organised form of discourse (see Kaplan 1993). Narrative framing, then, is a strategy to fixate certain meanings by developing narratives with a view to making a particular discourse hegemonic (van Buuren and Warner 2010). 
The chapter is structured as follows: after this introduction, we give a brief overview of the recent changes in Dutch flood risk management policies and of the policy narratives that have supported them. Next, we discuss three examples that illustrate various dimensions of the conflicts that emerged in the interventions based on the policy shifts towards spatial measures. We pay specific attention to the narratives used by parties in the conflicts to either support or contest these interventions. Thereafter, our analysis will compare the examples, noting similarities and differences in how conflicts developed and how these developments relate to the identified narratives and framings. We end with a short conclusion.

\section{From dikes to space: Dutch flood risk management policies at the crossroads}

\section{Dike reinforcement: 'battle against water'}

This section discusses the important stages in flood risk management policy, of which the cases discussed below are representative. Until the mid-1990s, dike construction as primary flood defence was the dominant approach in the Netherlands (Enserink 2004). The age-old narrative of 'battling against water' meant separating water and land through dikes (Wiering and Immink 2006). For centuries, the main rivers (Rhine, Meuse, Scheldt) had been straitjacketed, but their infrastructure suffered from bad maintenance. Immediately after the 1953 storm surge flood, sea defence was prioritised over the quality of river dikes. Only in the following decades, with more intensive land use and increasing value of economic infrastructure, more attention was given to river dikes. The resulting dike reinforcement policy under the aegis of the Rijkswaterstaat was characterised by an authoritarian government style with little room for deliberation or citizen engagement (Pröpper and Steenbeek 1999).

The Rijkswaterstaat distinguished different flood safety levels, anchored in law, for different regions (Enserink 2004). The probability norm for the river dikes in the Netherlands was one flood event per 1,250 years, based on an estimated (design) discharge of $16,000 \mathrm{~m}^{3} / \mathrm{s}$ for the river Rhine. ${ }^{1}$ River safety was largely viewed as a technical engineering problem, solvable by modelling combined with costbenefit analysis. The agency's engineers used probabilistic arguments - the possibility of flood occurrence-using past events to predict future effects (Enserink 2004). While the water boards were in charge of implementing dike reinforcements, the provinces, as competent authority, had to weigh the different interests. Protests were organised by environmental organisations that acknowledged the values of natural landscape and cultural heritage. Citizens protested against the demolition of houses and loss of cultural and landscape values as a result of dike enhancements. This sharpened the polarisation between proponents of dike enforcement, particularly engineers propagating 'safety first', and its opponents, mostly citizens and environmentalists defending natural and cultural landscape values. As a result, the programmes were adapted, while the Rijkswaterstaat incorporated ecological concerns in its policy (Wiering and Immink 2006). 


\section{The spatial turn: making 'room for the river' and 'accommodating the water'}

High-water events in 1993 and 1995 demonstrated the susceptibility of river dikes to floods, for instance, through undermining of the dike by piping (Te Linde, Aerts and Kwadijk 2010), which necessitated the Rijkswaterstaat to act. While a crash programme of additional dike enhancements, the Delta Plan for the Large Rivers, was implemented in the late 1990s, discussion started on whether such measures were sufficient for the long-term. This discussion led to an apparent paradigm shift in flood risk management, also in view of climate change and its possible implications for river discharges (e.g. changing rainfall patterns, snowmelt). River widening was increasingly seen as an effective flood risk mitigation strategy (Wiering and Immink 2006). Whereas in the old paradigm, water management had been based on resistance through dikes, the new idea promised more flexibility and resilience against extreme discharges. Policy-makers changed from a probability approach towards a risk approach (Wolsink 2010). Space became the guiding principle in river management and land-use planning. These changes required the Rijkswaterstaat to change its tack, as land behind the dikes is needed for dike relocations, bypasses and water storage. This required institutional changes at all levels, including different forms of governance (Wiering and Immink 2006).

The main policy instrument to realise this shift, the Room for the River programme (Ruimte voor de Rivier), ${ }^{2}$ aimed at improving safety against flooding of the Rhine and Meuse by accommodating a discharge capacity of $16,000 \mathrm{~m}^{3} / \mathrm{s}$ for the Rhine and $3,800 \mathrm{~m}^{3} / \mathrm{s}$ for the Meuse (Ministry of Infrastructure and the Environment 2012a, 2012b, 2012c). The second objective was improving the 'spatial quality' of the river landscape. The Rijkswaterstaat engineers, however, normatively prioritised flood safety over other river-related values and functions, such as landscape and biodiversity (Wiering and Arts 2006). Note that in water engineering, scientific and policy circles, there was an absence of full agreement on this shift towards spatial measures. Its efficacy was also questioned, among others by those who put their bets on much bigger 'climate dikes'.

As with earlier dike enhancements, the Rijkswaterstaat could not prevent citizen protests against interventions in the landscape behind the dikes, which were seen locally as disturbing existing communities, landscapes and rural livelihoods (e.g. farming and livestock enterprises). Although protesting citizens were not against measures for flood prevention, they often questioned the need to implement them in the way or at the location designated by the government. Thus, many protests were negatively characterised by a NIMBY (Not In My Back Yard) attitude on the part of local stakeholders confronted with Room for the River plans.

Protesting groups often questioned the axioms underpinning flood interventions, such as the design discharge norm of $16,000 \mathrm{~m}^{3} / \mathrm{sec}$ for the river Rhine. Some projects even had to meet a $18,000 \mathrm{~m}^{3} / \mathrm{sec}$ norm, which was not included in the legislation. ${ }^{3}$ These assumptions were the weakest part of the justificatory arguments framing the governmental plans for water interventions as necessary and effective. Protesters 
argued that, even during the biggest ever quantitatively documented flood, in 1926, the discharge had reached only $12,600 \mathrm{~m}^{3} / \mathrm{sec}$. In some cases (e.g. calamity polders and the river bypass Varik-Heesselt; see below), protesters pointed out that, given the current flood risk management policies and dimensions of the dikes in upstream Germany, such quantities of water can never reach the Netherlands. Other citizen strategies included publicly questioning the proposed economic or demographic growth model (e.g. the Kampen case; see below) or the measure itself, by presenting an alternative plan, hiring expert knowledge, mobilising politicians, inhabitants and the media, and forming alliances with government agencies and societal organisations.

\section{The Delta programme: 'working together with water'}

In 2008, the (second) Delta Committee, a political advisory committee, presented a vision for long-term protection of the Netherlands in a changing climate (Boezeman, Vink and Leroy 2013). Its advice, titled 'working together with water', suggests active cooperation between 'us' (citizens) and 'water' (sea, rivers). The national collective focus is stressed by framing flood safety as a public interest (Vink et al. 2013). Based on this advice, the Ministry of Transport, Public Works and Water Management established a new Delta programme. While Room for the River had a limited time frame (2000-2015), the time frame of the Delta programme is much longer (into 2050 and even 2200) (Boezeman et al. 2013) to make adaptation to long-term climate change effects possible. Contrary to Room for the River, the Delta programme was disconnected from the traditional political process. The Dutch Cabinet appointed a Delta commissioner to connect the different ministries, governmental layers, entrepreneurs, civil society, and citizens (Vink et al. 2013). The Delta Committee's legitimising argumentation is that flood safety is too important for political bargaining and budgetary negotiations, requiring a depoliticised, topdown mode of governance (seeVink et al. 2013: 97, Table 1). To justify its long-term scope and depoliticized mode of governance, the Delta Programme refers to the climate scenarios of the Dutch meteorological expert centre Koninklijk Nederlands Metereologisch Instituut (KNMI), and to the international study Rheinblick 2050, stating that, in 2100 , the possible range of design peak discharges for the river Rhine will lie between 17,000 and $21,000 \mathrm{~m}^{3} / \mathrm{s}$.

Water governance arrangements in the Delta programme framework are particularly directed at, and open to, governmental actors; planning is delegated to regional and local governments, which need to co-finance flood risk projects. There is a special budget for 'co-linking' (meekoppelkansen) to garner financial support from the region. The point of departure is that co-financing a river project gives the cofunder a voice in the final project plan, such as including a new harbour to generate new economic activities in the region. Acting boldly, the Delta programme started planning river projects without being supported by a legal framework, as the new dike and design discharge norms of the rivers ${ }^{4}$ still needed to be politically decided on in parliament. In the meantime, a Delta fund, a Delta Act and Delta decisions were instated. 


\section{Losing the political? Three cases of depoliticised flood risk management intervention}

As shown in this overview, whatever the governance arrangements, protection measures against flooding have been contested since the 1970s. Whether centring on dike reinforcement or including spatial measures, conflicts about river interventions abound. The past two decades have seen a gradual shift away from top-down planning towards a more participatory style of intervention including 'stakeholder involvement'. According to a corporate brochure of the ministry responsible, creating room for the river is making 'room for governance' (Ministry of Infrastructure and the Environment 2012c). However, as we will argue, the flipside of this development is a trend towards depoliticisation of decision-making. For instance, it is up to experts and policy makers to determine what risks are acceptable, while societal support is sought by claiming considerable regional economic benefits from colinking. Stakeholder meetings are organised without clear rules, agenda or outcomes. Citizens are heard in special meetings, but objectives, responsibilities and scope for influence remain unclear. Who is in charge? The regional government because of its lead position in proposing river plans? Or will the Delta commissioner finally decide? The governance arena is increasingly difficult to grasp for citizens.

Social scientists and development sociologists (e.g. Cleaver 1999; Harriss 2002; Mouffe 2005a, b) would explicitly recognise forms of protest, resistance and 'counter-development' (Arce and Long 2000) as relevant and functional forms of participation. However, policy-makers tend to be conflict-averse (see Shore, Wright and Però 2011). In The Anti-politics Machine, Ferguson (1990) makes the point of depoliticisation specifically for the workings of 'development' interventions, in which discourses of neutral and universal expertise hide the basically interested and biased character of development interventions. Mouffe (2005a: 9) has further developed such criticism of depoliticisation into a more fundamental criticism of the marginalisation of 'the political', the basic antagonisms that constitute societies. According to Mouffe, conflict and antagonism are inherently part of a democracy based on the plurality of values. The political arena is the place to come to terms with such antagonisms by establishing a hierarchy among political values (Mouffe 2005b). Concurring with Mouffe, we argue that giving room to 'the political' may be a more productive way of dealing with conflicts than assuming consensus or trying to enforce it through consensus-seeking processes that are not acknowledged by all contending parties.

In the following sections, we discuss three interventions directed at the river Rhine and its branches, in which conflicts about spatial interventions emerged. ${ }^{5}$ The first one represents the period of transition from the 'battle against water' towards the 'spatial turn'. It focuses on the Ooijpolder in Gelderland Province, where plans for calamity storage of water from the river Rhine led to massive protests by citizens' organisations against the intervention. The second intervention, in the Room for the River programme, discusses conflicts developing around the construction of a bypass for the river IJssel (a branch of the river Rhine) in Kampen, Province of Overijssel. It 
shows that 'water conflicts' are not necessarily about water alone. The third intervention concerns plans under the Delta programme for another river bypass for the river Waal (another Rhine branch), in Varik and Heesselt. ${ }^{6}$ Some inhabitants of these villages were organising themselves against these plans. As we will argue, taken together, these manifestations of spatial-infrastructural policies in the last two decades show two important things: first, they provide a relevant comparative understanding of the changing trends in river flood management and the consequences of these for water governance; second, they show the role of conflict, how conflict is dealt with, and the important narrative elements used to justify or contest interventions in relation to the interests and objectives of the actors involved.

\section{From dike enhancement towards radical spatial solutions: conflict about the Ooijpolder}

As noted, the Dutch flood management debate showed changes after two high-water events in the 1990s. Flood risk gained prominence again, the main argument being that rivers had historically lost their space while population and economic values behind the dikes had continued to increase. The old recipe for 'fighting the water', dike reinforcements, was increasingly seen as having reached its limits. Gradually, the climate change argument emerged and advanced as a legitimising narrative for the shift towards spatial measures (Vink et al. 2013). The new government (the Rijkswaterstaat) narrative started moving away from guaranteeing 'safety behind the dikes' towards stressing an omnipresent 'residual risk', even with well-maintained dikes. It stressed the need to move from resistance towards accommodation and 'living with water' (see Wiering and Driessen 2001; Wiering and Immink 2006). Thus, simultaneously with a crash programme for dike enhancement in reaction to earlier high waters (to deal with bad dike conditions and overdue maintenance), the Room for the River policy was conceived in 1996 to create more space for water to deal with residual risk.

There was a major problem, however: the earlier government narrative of 'sleeping safely behind the dikes' had gradually made the Dutch less aware of flood risk and left them unprepared for small floods or disaster. ${ }^{7}$ The intended policy shift towards spatial measures and 'living with water' required a higher awareness of flood risks. Only broad acceptance of the flood risk narrative under construction would create legitimacy for the planned Room for the River interventions. In early 2000, therefore, the functionary responsible, Vice-Minister Monique de Vries, decided to use a rough remedy against this low flood risk awareness. During a meeting to present the Room for the River policy line, she also launched plans for the selection and establishment of so-called calamity polders. ${ }^{8}$ This concept was part of the new flood risk management narrative, legitimising a search for spatial solutions that were to affect many inhabitants. Contradicting the earlier policy — safety behind the dikes had been the main source of political legitimacy of the Rijkswaterstaat - the minister now openly stressed that absolute safety behind the dikes was impossible and that the 'residual risk' can no longer be covered exclusively by diking. Spatial solutions 
were presented as unavoidable, and 'calamity polders' were posited as the safety valves to save densely populated and economically developed areas located downstream of these polders. Designation and redesign of a small number of strategically located polders as 'calamity polders' was assumed to make 'controlled flooding' of these polders possible, thus reducing uncertainty and insecurity by making evacuation and protection against damage in the calamity polders plannable (see Roth and Warner 2007, 2009).

The plan for 'calamity polders' was widely covered in national and regional media, creating a stir among the population of the designated areas, particularly in the Ooijpolder, a scenic area with a 2003 population of around 13,000. As the plans caught them completely unaware, the inhabitants were furious and felt bypassed by the policy process. A wave of protests from citizens, Gelderland Province and municipalities, farmers' associations, regional Chamber of Commerce, and employers' organisations ensued. Water experts from Delft University were critical of the scientific justification for the plans and provided counter-expertise. Gelderland Province publicly declared its unwillingness to cooperate in implementing the calamity polders. Realising the conflict potential of the issue, the government decided to postpone its decision and instituted an expert commission, the Commission on Calamity Polders, appointed in 2001 to advise, among others, on the appropriateness of calamity polders as a solution, area selection and its consequences (Commissie Noodoverloopgebieden 2002).

Notwithstanding the commission's self-image of 'rational experts', the way it operated created growing distrust among critics of the plan and rapidly turned the issue into a conflict in which the parties came to be at loggerheads. The commission had derisively labelled the initial protests as based on 'emotion', uncritically accepted climate-adjusted peak river discharge volumes ${ }^{9}$ as a point of departure for its work, limited its interactions with the general public to a number of organisations regarded as representative of society at large, and started propagating the idea of calamity polders as a kind of 'airbag' to cushion the river system from crashes. Unsurprisingly, in its 2002 report, the commission advised designation of calamity polders in three areas, including the Ooijpolder (see Roth and Warner 2009).

With the Vice-Minister opting for 'decisiveness' (that is, implementation) on the basis of this report, calamity polders seemed to be in the can. However, a growing number of Ooijpolder dwellers began to realise that this was serious business. The designation of their polder for emergency storage meant property prices would plummet. Initially, protests therefore came from property owners, farmers and entrepreneurs, with support from a local branch of the RABO bank, where most inhabitants (especially farmers) had an account. The chairman of the expert commission also happened to chair the national RABO bank's supervisory board. In the course of 2002, the local bank director took the initiative of inviting the chairman of the expert commission to come to the polder and explain the plan directly to the inhabitants.

It is noteworthy that this had not been done earlier. The previous year, the communications section of the Rijkswaterstaat had prepared a 'stakeholder analysis' about the calamity polder issue. However, instead of bringing contrasting opinions around 
the table, it was advised to turn 'dangerous' stakeholders - the unruly ones, who protested against the plans - into supporters of the plans by bombarding them with propaganda on the calamity polders (see Roth and Warner 2007, 2009). The information meeting with polder dwellers, where the idea of calamity polders had been propagated but no serious debate had been possible, had given opponents the final push to organise themselves as a platform against the plans of creating a calamity polder. The chair of the well-organised citizen group, Hoogwaterplatform (High Water Platform) explained the citizens' mood: 'It [the meeting] was a shocker [for the citizens], its typical top-down approach ... Until then, the possibility that the Ooijpolder might be designated as a calamity polder was withheld from them. Before, there had been neither commotion nor resistance. The publication of the commission's report, which the regional newspaper paid attention to, and the important role of the local bank [that organised the information meeting] stimulated the citizens' awareness of the plan. The chair [of the commission] was invited, a very kind man; there was no anger among the 400 citizens. The question arose: "what do they want?" The meeting made that very clear to the citizens. ${ }^{10}$ The citizen group mobilised the citizens and organised counter-expertise on river engineering and hydrology, to critically review the plans and engage in debates with experts propagating the measure. A retired Delft professor of civil engineering, Wybrand van Ellen, dubbed the polder a 'bathtub' (Aarden 2003).

Van Ellen stated that water retention in emergency areas is ill-conceived:

In a delta like the Netherlands with many rivers, it is important that the river water is flowing rapidly to the sea. It is not useful to store it in water retention areas like emergency retention areas. Some eight- to nine-metre high dikes are needed near the pumping station at the entry of the polder to hold the water in the retention area. ${ }^{11}$

Around villages, the same high dikes will be needed, the so-called mini polders, resulting in a 'bathtub' effect in case of a high water period (see Figure 3.1). Technical and legal counter-expertise were also needed to develop alternative plans, as the Hoogwaterplatform wanted to avoid accusations of NIMBY-ism.

At a later stage, as all attempts to start a dialogue had proved in vain, the group declared the Vice-Minister the enemy. Instead, the focus shifted to intensive contacts with politicians, providing them with regular updates on research and inviting them for a guided tour through the polder. Further, the group strengthened its transboundary alliance with the Germans. The Ooijpolder borders an area called Düffel in Germany; the two areas are actually one polder system. The Dutch planners had failed to share the calamity polder plan with their neighbours; neither the German regional government nor the inhabitants of the Düffel were pleased with the Dutch plans, which initially did not include a border dike to prevent calamity storage water from flowing into Germany! This created an opportunity for forging a transboundary alliance against calamity polders.

The protests generated several critical research initiatives that gradually undermined the commission's advice: inter-regional research between Gelderland 


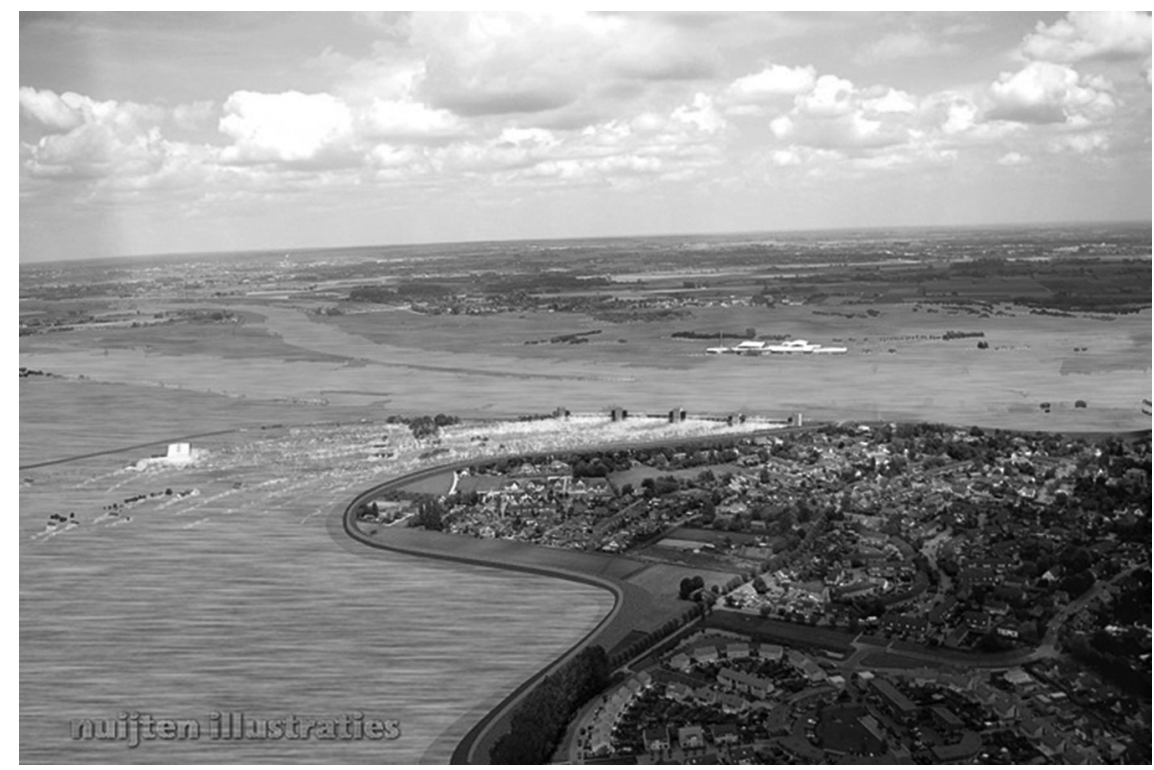

FIGURE 3.1 Illustration of the inlet of the proposed retention area of the village Millingen in the Ooijpolder. At a later stage, the water will flow into the village dike ring, the so-called bathtub effect. Source: Studio Nuijten, Kekerdom

Province in the Netherlands and Nordrhein-Westfalen in Germany; critical research by Delft University, commissioned by Dutch and German municipal authorities; and a critical study on effectiveness, cost and benefits of the calamity polder concept. ${ }^{12}$ The Hoogwaterplatform continued stressing that the inhabitants were willing to accept the plans on the condition that alternatives had been seriously researched and proven ineffective, and the calamity polder demonstrably proven to be the best solution. Eventually, this strategy proved effective; the tides turned against the commission. The demise of the calamity polder plan took place in 2005, when the Dutch Parliament adopted a motion demanding the transfer of the budget for calamity polders to the Room for the River programme.

\section{Kampen: river bypass as vehicle for urban planning}

These conflicts about plans for calamity polders, imposed on society in a top-down way, coincided with the planning of Room for the River projects, characterised by narratives of participatory planning and 'governance'. It was expected that urban areas would show a larger support base for change in this way (van Drimmelen and van Buuren 2004). However, belying the dream of flood-safe urban development, the new interconnectedness of water and land-use planning generated conflicts of its own. Developments around the Kampen bypass illustrate how water conflict is often not only about water, but a convenient flashpoint for other contentious 
issues. Although Room for the River was declared an administrative success (ten Heuvelhof et al. 2007; Rijke et al. 2013), several of its 34 projects were confronted with fierce opposition.

Along the river IJssel, branch of the Rhine, a set of river interventions had to be realised to loosen the river's bottleneck in urban areas by creating 'opportunities for new urban functions and landscapes.'These interventions were presented as 'a string of pearls', one of which is the IJssel delta. The IJssel delta, in which Kampen is situated, spans an area of approximately $162 \mathrm{~km}^{2}$. It has a population of about 60,000 . The region is vulnerable to flooding; Kampen is in fact flood-prone from two sides, Lake IJsselmeer and the river IJssel. Kampen's built environment, which runs up into the floodplain, is considered a bottleneck for future river discharge (see Warner and van Buuren 2011).

In 1995, Kampen narrowly escaped being flooded. Among alternatives to increase river capacity inventoried at the national level in 2001, a flood relief channel (bypass) seemed the most effective and cheapest alternative. Widening the river and lowering the floodplain level by $1-1.5 \mathrm{~m}$ as a short-term measure, and a bypass as a long-term strategy to save the Kampen bottleneck from larger influx in the future, became the preferred solution. Laid down in a 2003 parliamentary decision, a spatial reservation was to be made there as a 'climate buffer', banning future development. The Kampen bypass will be the last Room for the River project to be finalised, probably by 2025 , with costs now estimated at a staggering 426 million Euros.

Kampen's municipal administration felt it was carrying the costs of the bypass while missing out on the benefits, as the bypass will also protect many non-urban citizens. The bypass is projected in an area with many planned developments, including a motorway, a railway, housing, a river bypass, and nature. The provincial authorities sought ways to combine the bypass with urban expansion, upgrading the capacity of two motorways and a new railway to connect the north-east with the western conurbation, plus a new station. There were also plans for development of 300 hectares of 'new nature', ${ }^{13}$ for improving the regional agrarian structure and for strengthening infrastructure for tourism and recreation. In early 2005, the Ministry of Housing and Spatial Planning mandated Overijssel Province to develop an integrated 'regional development plan', including the bypass. After pro-project parties won the 2006 local elections, Kampen's municipal authority joined the project enthusiastically.

A regional development plan with so many land-use functions has to meet several opposing interests, which will obviously lead to conflict. A participatory process was started for organising a smoothly running project. In 2006, 100 participants from 32 organisations were involved in a massive consultation on the project. In an intensive process, five scenarios were developed by a small intergovernmental team (Van Buuren and Warner 2014). When farmers in Kamperveen complained about the plans, they were involved in the development of a new alternative. The inhabitants of the hamlet of Noordeinde in the neighbouring province of Gelderland, who feared being washed away in a flood event, were promised that the bypass would not cross their territory. The project manager sought to make the bypass inevitable by already starting to buy farmland from farmers known to be willing to sell, and 
through upfront investments in an infrastructural 'node' (Grijzen 2010): the bypass would cross the railway line twice, necessitating a tunnel and a flyover. A 30 million Euro 'node' would enable a smooth crossing. Various trajectories and formats for the bypass were mooted, including an 'open' and a 'closed' model. An open, navigable bypass would be more dynamic, but would also require higher dikes and raise groundwater levels. It was therefore opposed by the regional water management board (Groot-Salland) and farmers in the region. In the end, a closed bypass was chosen.

Among several conflicts, the conflict between flood security, nature and landscape values, agrarian interests and infrastructure was presented as solvable and conveniently backgrounded the 'growth coalition', a coalition of local and provincial governments, underlying the planning. The provincial authorities of Overijssel and the city of Kampen eyed the area for urban development and recreational navigation, which they felt could attract well-to-do residents. They were driven, among others, by the prospect of paying for the bypass from the rise in land value. Put simply, local authorities see growth as prestigious. The local and provincial governments negated the interests of those living in the area of natural beauty south of Kampen, where dairy farmers also operate. A municipal hearing in 2010 sought to put an end to the confusion. But while the formation of a 'project core group' in 2010 brought more clarity to the process, for those who would be affected by the plans, it also allowed opposition to harden (Grijzen 2010).

An anti-growth coalition had formed early on, an unusual alliance consisting of nature conservationists, farmers, religious conservatives, and old-school socialists. Landscape conservationists resisted urban expansion across Zwartendijk, a village famous for its national cultural heritage and built in 1302 to save the country from the Zuiderzee floods. ${ }^{14}$ Zwartendijk also delimits the built-up area of Kampen town to the South. Their vehicle, the Werkgroep Zwartendijk (Working Group Zwartendijk), worried that dikes protecting the bypass would become so-called climate dikes. Climate dikes are higher and broader levees than what current necessity dictates, with a view to meeting future extremes, while also permitting urban development on top of them. They therefore opposed both the dike and the urban development. Lower levels of urban growth would obviate the need for building across the Zwartendijk barrier.

Werkgroep Zwartendijk mobilised knowledge, including demographic projections that foresee a population slump in the region from the 2010s. They showed that the development plans were based on unrealistic projections that assume that housing supply generates demand. While scientific demographic prognoses predicted a slump, municipal authorities preferred to go with a privately developed demographic model, Primos, that also included 'municipal ambitions' in the (usually bullish) prognoses.

The opposition, moreover, gained momentum when it transpired that the fifth alternative developed by an inter-governmental team may make the region safer except for Kampen. With the town embanked on all sides, water would not drain to the South but might rise fast to up to 2.7 metres, and thus claim many more 
casualties after a dike break. Werkgroep Zwartendijk was informed about this scenario which was found in a report cited in the Environmental Impact Analysis (HKV 2005): 540 lives and 1.4 billion Euros could be lost, as against 100 fatalities and 400 million in losses without it (Sligter 2009). This boosted Werkgroep Zwartendijk's opposition to the bypass, even allowing for a different urban expansion location.

Displacing the 'string of pearls' as the central image, the Werkgroep Zwartendijk ran with the 'bathtub' moniker, coined by an affected local farmer, to support his conservation platform. Since the drafting of the report, the plans have changed substantially and their impact has been revised accordingly - the 'bathtub' label, however, stuck and changed the narration and dynamics of the conflict. The safety discourse boomeranged (van Buuren and Warner 2014), making the bypass difficult to accept (Figure 3.2).

Another victory was won in an administrative lawsuit filed by Werkgroep Zwartendijk, in cooperation with, among others, another conservationist association (Vereniging Voor Natuurstudie en Bescherming IJsseldelta). The Council of State (Raad van State, the highest Dutch administrative court) quashed plans for new development in February 2015: the Council failed to see a pressing need for 1,300 luxury properties with 1,100 mooring places, dismissing the private report on development potential (Satink 2015). It also ruled that the bypass should not be made fully

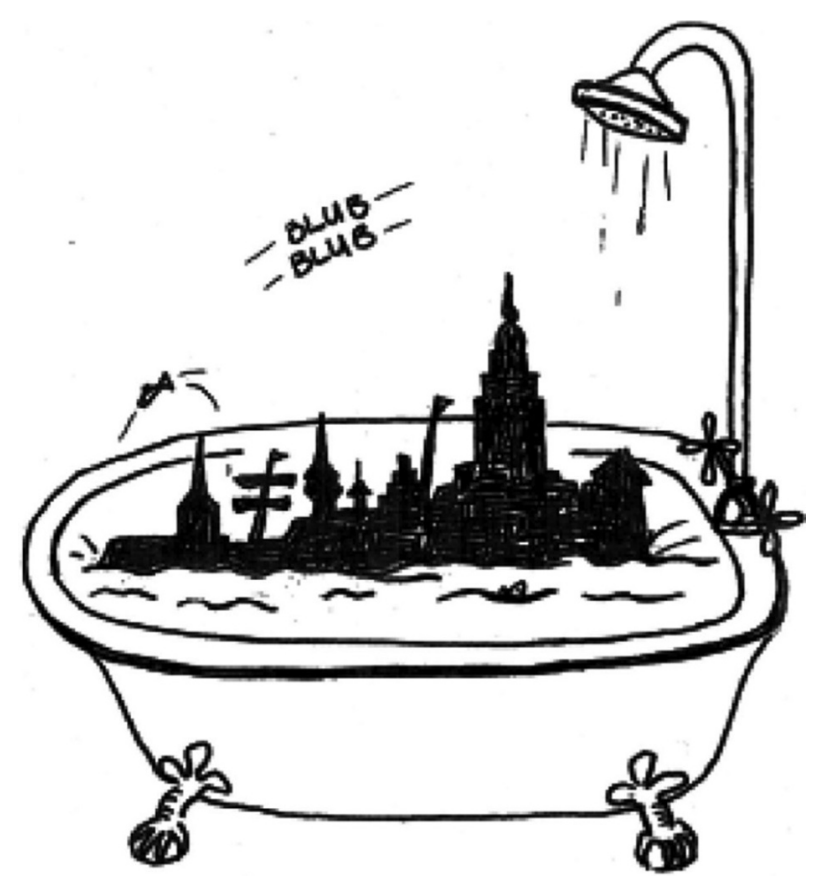

FIGURE 3.2 Kampen as a bathtub (c/o Werkgroep Zwartendijk). Source: Werkgroep Zwartendijk. http://www.zwartendijk.nl/bestanden/flyer.pdf (accessed 11 December 2018) 
navigable and claimed that it clashed with European 'Natura 2000' (nature conservation) regulations by disturbing bird habitats. Meanwhile, the political climate for urban expansion had changed. In 2016, the province of Overijssel and 10 municipalities including Kampen pledged not to build more than the projected housing development (RT Oost 2016). The speculative 40 million Euros to be made from housing projects according to 2007 projections had turned into a 43 million Euro loss by 2016. ${ }^{15}$ Kampen then looked into alternatives for a 'bypass for the bypass' that would still enable navigation. Tourism and economic development remain valuable to Kampen, but so are the birds and the landscape to conservationists.

\section{Any real alternatives? Contested plans for a river bypass in Varik-Heesselt}

Since 2010, when the Delta programme was started, the Delta commissioner worked in a multi-level governance setting on measures to further reduce flood risk beyond 2015, with a view to managing future climate extremes. The search for so-called promising river projects was delegated to regional governments, in this case the Gelderland Province. The bypass in Varik and Heesselt, the two wards of the municipality of Neerijnen along the river Waal, was considered 'promising' because of an estimated lowering of the peak discharge level by up to $50 \mathrm{~cm}$. When some citizens discovered an outline of the plan on a local website, they organised themselves into a citizens' action group called 'Waalzinnig' ('Rhinediculous'). ${ }^{16}$ They questioned the need for the bypass and the grounds for using the $18,000 \mathrm{~m}^{3} / \mathrm{s}$ norm for the river Rhine, which was not yet required by law. They specifically questioned whether this discharge level could even enter the Netherlands at all, in view of the impact of German flood policy. ${ }^{17}$ Let's consider the Delta Commissioner's and the Minister of Water Management's respective replies as disseminated through the news media.

In a media interview, the Delta commissioner admitted that nowadays expropriation is difficult:

[I have] no overriding authority, but people know that I will make the final proposal and I can organise it in such a way in The Hague [seat of government] that it [the bypass] will likely be accepted [as a Delta decision]. Sounds cool, huh? ... Of course, there are opponents. A number of houses will need to go, but that would also be the case for dike reinforcement.

(NRC 2014)

The Delta commissioner has the institutional means to act. 'There is an act, the Delta Act, there is a programme, the Delta Programme. There is money [the Delta Fund], we are taken seriously. Whatever we invent, can be implemented' (NRC 2014). The former Minister of Water Management had a message for the citizens of Varik and Heesselt. She claimed to have learned from earlier experiences that once citizens understand why the bypass is planned and what its private consequences are, support will increase: 'Citizens will need to trust the government in compensating the costs 
for eventually moving out. But we will take the measures to increase the safety of four million citizens in the area' (De Gelderlander 2014). The minister's reaction is a follow-up of the government mantra that citizens will be safe behind the dikes.

At the end of 2013, the province and the municipality invited 22 citizens to become members of a 'sounding board group', ${ }^{18}$ among other farmers and fruit growers holding land in the projected bypass area. According to the provincial project manager, they could discuss the plans and express their concerns, so their advice could be used in decision-making. ${ }^{19}$ In the sounding board group, proponents and opponents of the bypass were represented. During the process, most proponents changed position because of the safety issue: In case of a dike breach, the polder in which the villages Varik and Heesselt are situated, will rapidly fill up with water viz. the bathtub effect; consequently, residents won't have time to evacuate.

The members worked on three bypass scenarios. In the first one, the "compact scenario', some 12 houses would have to disappear to make space for a deep and narrow (300 metre) bypass, also known as the 'blue bypass'. Once in four years, on an average, water would flow through the bypass. In this area, there would be no room for housing and agriculture, but recreation and nature conservation could be developed. In the second, the 'space scenario', the width of the bypass would be narrow, in order to spare as many houses as possible. Later, the bypass could be widened up to some 800 metres. Once every 15 to 25 years, water would flow through the bypass. There are opportunities for housing (on mounds), sustainable agriculture, recreation and nature conservation development. The third, 'functional' scenario, for which some 30 houses would have to be removed, is a straight bypass with dikes and an inlet for giving space to the water. Once in four years, water would flow through the bypass. In the area, agriculture would be possible, but fruit trees would not survive. ${ }^{20}$ As a member of the sounding board, the chair of the resident group Waalzinnig criticised the three scenarios:

In fact, these three scenarios are not meant to be real alternatives ... The design is different, but the project remains the same ... From a technical perspective, the first scenario ... is not possible. If ... implemented, the water level in the Waal will decrease significantly, at the cost of shipping. The third alternative cannot function even as a channel. ${ }^{21}$

In June 2014, the 'promising' bypass project was included in the 'final preferred strategy' of the Delta programme for the Rivers. The Gelderland provincial council's white paper on regional development, Waalweelde West, was the forerunner in the list of proposed flood risk measures in this region. The village council opposed the bypass but had not been taken into account in provincial decision-making. Instigated by the village council, the responsible municipal executive councillor wrote a letter to the provincial delegate to express his concern. At the same time, the municipality was of the opinion that the planning process should continue (Brabants Dagblad 2014).

In the fall of 2014, Waalzinnig commissioned Wageningen University's Science Shop ${ }^{22}$ to critically review the legitimation of the $18,000 \mathrm{~m}^{3} / \mathrm{s}$ safety norm..$^{23}$ As already 
mentioned, among experts, the region is known as a 'bathtub' due to its deep polders and high dikes. Anticipating imminent flooding in 1995, 250,000 inhabitants were evacuated. Since then, dikes have been reinforced and groynes ${ }^{24}$ and other obstacles in river and flood plains removed. But according to the provincial delegate, both new dike reinforcements and a bypass are probably needed to guarantee the safety of the inhabitants. The citizens of Varik and Heesselt fear that they will be worse off: now it would take days to fill the bathtub with water, so inhabitants would have sufficient time to evacuate. With the bypass,Varik and Heesselt will be an island surrounded by dikes. It is feared that in a flood emergency, the bathtub' created between the river dikes and the new dikes along the bypass could rapidly fill up with water (DG 2016a).

The study conducted by the Wageningen Science Shop shows that first, there is no decisive scientific proof that the design discharge of $18,000 \mathrm{~m}^{3} / \mathrm{s}$ into the river Rhine in 2100 is realistic. Even with a much smaller water volume, parts of Germany will be flooded because the dikes are not dimensioned for such a water volume (see During, Pleijte andVreke 2016). So, the water will not reach the Netherlands in the first instance. Second, the assumptions, on which the technical arguments underlying the design standard are based, are not made explicit and hence cannot be criticised. With respect to the norms and measures in the field of flood risk management, there is no coordination with Germany. Those who are affected do not play any role in decision-making. The chair of Waalzinnig explained:

We asked Wageningen Science Shop whether it is able to scientifically underpin the legitimation of the plan for a bypass. We run a risk because the research must be independent, and outcomes might disappoint us. But we must not shirk from that risk ... and we are of the opinion that if the bypass is the solution, we should bow to it.

(DG 2016b)

While the local media picked up the story, the national media did not pay attention to the issue, nor did the national government react to the criticism expressed, among others, in the Wageningen Science Shop report. The provincial delegate did:

It is correct that we cannot prove that it $\left[18,000 \mathrm{~m}^{3} / \mathrm{s}\right]$ might happen. But inversely, others cannot prove that it won't happen. Our figures are based on assumptions which have not fallen out of the clear blue sky. The forecast will be sounder in the near future. The threat will not only come from Germany. Today, heavy rains are more common ... We cannot wait to take a decision until the moment we are unsafe. We are absolutely safe now, but not in the medium to long-term. Accordingly, we have to decide in late 2017 or early 2018.

(DG 2016a)

From a river hydrological point of view, this is a foolish plan based on a tunnel vision, creating a risky 'bathtub' situation for the villages concerned, and contributing little to nothing to regional development. In February 2018, the steering 
committee advised negatively on the bypass. Despite that, the province persevered in its support for the plans. In 2016, discussions about the bypass seemed to have totally stagnated, and a decision in favour of the bypass seemed likely. Waalzinnig had not been able to convince the more powerful governmental-administrative proponents. The Wageningen Science Shop report had caused some stir but did not become a game-changer. Members of the 'sounding board group' had their hands tied by the group's narrowly defined role (discussing and co-designing the alternative bypass options). In 2017, nonetheless, the situation changed radically. The turning point was the mobilisation and active engagement of several independent critical experts: picking up on the critical Wageningen Science Shop report and adding their own incisive criticism to the plans. They started working out alternative combinations of diking and interventions in the flood plains of the river. After several attempts to marginalise and delegitimise such critical alternative initiatives, critics could no longer be silenced. As a result, opinions changed and the plan was finally voted down in the national parliament in June 2018.

\section{Analysing conflicts about spatial flood risk management policies: the consensus bias}

This section will briefly compare the three interventions discussed above, noting similarities and differences with regard to the nature of the conflicts, legitimising narratives that play(ed) a major role, the constellation of competing positions, motives and interests that have driven them, and the degree to which the existence of conflicting views was allowed into the process or suppressed.

All three conflicts about river interventions (Ooijpolder, Kampen and VarikHeesselt) can be understood as arising from the fact that spatial flood risk management measures require land-use interventions in a densely populated country. Previously, infrastructural measures triggered conflicts about the impact of dike reinforcements on houses and landscapes adjacent to the dike. The shift towards spatial interventions has, however, a much wider impact on the river landscape, its inhabitants and other users. The leading narrative justifying such interventions is that dikes alone can no longer provide sufficient protection and cannot be endlessly enhanced. The climate change argument has strengthened this narrative since the mid-1990s (see Vink et al. 2013). The main institutional producer of this waterclimate-space narrative is the national water agency, the Rijkswaterstaat, backed by a wide variety of research institutes and consultancy firms whose livelihood is tied to floods. At the turn of the century, government communication on water safety was popularised, making use of slogans like 'living with water' and 'working together with water' (see e.g. Deltacommissie 2008).

Such narrative framings of 'the problem' and, by extension, its solution, are crucial in gaining public acceptance of and support for interventions; together they stress the urgency of the environmental challenge, the incontestable character of the analysis, and the appropriateness of the solution - though overstating it can easily backfire (van Buuren and Warner 2014). Thus, narrative framings are deployed to 
justify the intervention and, at the same time, legitimise the role of the government agency and the funding it receives. This narrative framing continued after a new institution, the Delta Commission, was established. Since then, narrative framing has been directed at various publics. Targeting the lower-level authorities, the need for jointly working on water is emphasised by delegating responsibilities and tasks, aimed at raising awareness among citizens about the long-term threat central in the communication strategy, based on climate scenarios from the Dutch meteorological institute. As a consequence of this divergence, alliances between lower-level governments and citizens were unlikely - as was the case in both the Ooijpolder and Kampen interventions.

A key similarity in the three cases concerns the important role of expert claims and the attempts by critics to mobilise counter-expertise to delegitimise the government narratives underpinning the relevance, urgency, efficiency, and benefits of interventions. While citizens mobilising counter-expertise played a crucial role in the Ooijpolder and Kampen interventions from the beginning of the project, this was initially not the case in the Varik-Heesselt intervention. Due to the multilevel governance setting and depoliticisation of the policy process, citizens in VarikHeesselt had no formal role in decision-making. Instead, citizens were considered as a 'support base'. In the final stage of the project, however, various experts fiercely criticised the underpinnings of the plan in a way that made it impossible for the proponents to sideline the criticism. They mobilised residents and formed a broad coalition, including nature conservation organisations and experts from universities.

Another similarity in the three cases is the emergence of other issues or 'development agendas', included in plans to get support of lower-level governments or the public. In the Ooijpolder and Kampen interventions, the narrative of 'room for the river' also means 'room for nature conservation and recreation' (Ooijpolder), enabling 'integrated regional development' (Kampen) and 'co-linking opportunities' (Varik-Heesselt). This did not resonate well with inhabitants and landscape conservationists, the spoilsports who failed to acknowledge development opportunities.

There are also differences between the three river interventions (Ooijpolder, Kampen and Varik-Heesselt). First, there are differences between the styles of planning of the interventions discussed above. In the Ooijpolder intervention, this style was unmistakeably top-down and hierarchical. The responsible government agency, the Rijkswaterstaat, did not see a need for involving citizens at an early stage, saw stakeholders as obstacles, and viewed communication with stakeholders as a one-way propaganda effort to make critics change their minds. In the end, the war was won by the well-networked Hoogwaterplatform, which cleverly decided to seek alliances and political support against calamity polders at all levels and even across national borders, rather than to engage in discussions with the Rijkswaterstaat. They meanwhile mobilised authoritative expertise to undercut the technical claims underpinning the necessity for the proposed water storage plan.

By contrast, the Kampen bypass, spearheaded by local authorities, tried a very inclusive and elaborate participatory process, involving a variety of local groups. However, this involvement was set as the exercise of solving a conflict over space 
faced with multiple development claims. The Working Group Zwartendijk, in collaboration with a conservationist association disputing the need and desirability of this development, was blindsided. They too uncovered that the axioms buttressing the intervention, of both flood safety and regional growth, were based on unrealistic scenarios. They managed to change the discourse and to win an administrative lawsuit concerned with curtailing developmental ambitions. Their anti-growth activism swaying the political tide was also helped in no small measure by the economic crisis forcing authorities to revise and downscale their plans.

Finally, the Varik-Heesselt bypass shows a strictly hierarchical government style, based on depoliticised flood risk policy in which citizens do not have any influence. Citizen involvement was particularly directed at legitimising the plan for a bypass and giving inputs for its design, but stopped short at the question about its functionality, necessity and availability of real alternatives. Rather than including citizen values, the lower-level authorities marginalised the citizens' critical comments. The role of the Delta Commissioner was key: he either invoked his authority at crucial moments during the planning process or was relatively invisible, avoiding direct contact with citizens. Here, too, citizens called on science and counter-expertise to criticise the assumed need for a bypass in their backyard.

In all the cases, the critical expertise mobilised was not publicly available to citizens and sometimes even intentionally obscured. Technical consultants' scenarios casting doubt on the safety impact of the river interventions were 'buried' in public reports and, in the Ooijpolder case, even initially denied. The consultants involved were in no mood to draw public attention to themselves, as that may disqualify them from obtaining future assignments. In the Varik case, the Wageningen Science Shop even met with initial university-imposed restrictions on publishing its critical study on the rationality of the safety assumptions. While the Wageningen Science Shop is still predicated on serving civil society, the university has increasingly become a 'concern', relying on paid public and private assignments. The aura of consensual decision-making, buttressed by economic interdependence, was not to be broken by enterprising critics claiming 'voice' in the policy arena. However, as evidenced by the parlimentary decision in 2018 not to implement the bypass plan, this strategy has clearly backfired.

\section{Conclusion}

The standard representation of latent or open water conflict by government agencies in the Netherlands is to deny such conflict. Despite well-intentioned decentralisation and participation efforts, the Netherlands water sector remains beholden to a technical discourse, bypassing debates over values, and relegating opponents to a powerless 'sounding-board' council. The attempt to include opponents was rarely pursued. Two out of three (planned) river interventions discussed here, VarikHeesselt and Ooijpolder, were conducted in a top-down manner, underpinned by specific flood risk management policy. In the same interventions, top-down decision-making was justified by legitimising narratives characterised by highly 
paternalistic language. The third river intervention, Kampen, a regional alternative to the bypass, was much more inclusive, but excluded alternatives based on values different than growth. In each case, local stakeholders feared the river intervention would create 'bathtubs' or otherwise reduce rather than enhance their safety. The 'bathtub' proved a powerful image in the narrative of the opposition, iconic for these conflicts that can tip the discursive balance.

In each case, there was a lack of a debate on values. Opponents discovered semi-hidden information and access to 'facts', that is, expertise undermining the interventions' guiding assumptions. Once outside the circle of water professionals, this expertise became ammunition in the 'war' against river interventions. Before Varik-Heesselt was in the final decision-making stage, there was still some scope for avoiding the frustrations experienced in the Ooijpolder and Kampen cases and for confronting local worries head-on. This opportunity was, however, not seized in the basically top-down and technocratic decision-making culture of the Delta programme, and the plan was finally voted down.

All three Dutch river interventions discussed here, whether top-down or more participatory, were conflict-averse. Conflicts are elided from the process, hidden from view and covered by narratives of consensus. It is no coincidence that the Dutch self-image of inclusive consensus-seeking, 'poldering', tends to take the political out of decision-making. Safety from floods is presented as so important that political quibbles should give way to decisiveness from the top down. As we have shown in this chapter, flood risk management, including river interventions like bypasses, is inherently about struggles over space between various, often diverging, interests, varying from public interest of flood safety (national and regional government), economic interest (the infrastructure and housing lobby) to private interest (citizens) and nature conservation interest (environmental organisations). Both flood risk management and land-use planning in the Netherlands are cloaked in technical rationality and therefore operate as an 'anti-politics machine' (Ferguson 1990; De Jong and Duineveld 2013).

\section{Notes}

1 This means that river dikes were dimensioned for a once in 1,250 years flood probability, assuming that the river system should be able to cope with a (maximum) discharge of $16,000 \mathrm{~m}^{3} / \mathrm{sec}$ (cubic meters per second) for the river Rhine.

2 See https://www.ruimtevoorderivier.nl/english/ (accessed 15 September 2015).

3 The design discharge was increased as a result of the high-water events in the 1990s and, later, in reaction to growing concerns about climate change.

4 Basically, the water volumes that the dikes should be able to contain, given certain risk standards. These are now to be complemented by norms on individual and collective risk exposure.

5 All three interventions have been researched by the authors of this chapter, using a combination of policy research, ethnographic methods, in-depth interviewing of a widely diverse range of respondents, and analysis of policy documents and media coverage. The Ooijpolder case study (situated in the eastern part of the Netherlands) was carried out from 2000 to 2005, the Kampen case study (situated in northern part of the Netherlands) 
was conducted from 2004 to 2015, and the Varik-Heesselt case study (situated in the centre of the Netherlands) was carried out during 2014-18. All authors were engaged in the Ooijpolder case study, while Jeroen Warner studied the Kampen case, and Dik Roth and Madelinde Winnubst studied the Varik-Heesselt case.

6 The plans for this river bypass were shelved in February 2018. After growing local protests and the mobilisation of critical counter-expertise, a steering committee, consisting of representatives of the province, water board, municipality, and 'sounding board group' (see below), advised negatively on the bypass plan. A final (national) government decision on the issue is expected in the course of 2018 .

7 Until the recent past (and even nowadays in some places), inhabitants of the riverine landscapes were better prepared: no expensive and vulnerable carpeting on the ground floor, hooks in the walls to lift furniture whenever needed etc.

8 A polder is a flat and low-lying area surrounded by dikes and reclaimed from sea, floodplains or coastal marshes. The water level in the polder is controlled by pumping devices (originally windmill-powered). A 'calamity polder' is a polder located upstream of areas to be protected along the river, designated for temporary water storage during extreme discharges. The term 'polder' is also used as a verb, as 'poldering', a tradition of inclusive consensus-seeking in negotiations, with which the struggle against the water is often associated.

9 Key issue was the assumption that a design discharge of $18,000 \mathrm{~m}^{3} / \mathrm{sec}$ or even higher could enter the Netherlands through the river Rhine, justifying the search for additional measures to deal with the 'residual risk'.

10 Interview with H.B.A.M. Sanders, Chairman of the Hoogwaterplatform (Kekerdom, 7 June 2005).

11 Interview with Marieke Aarden, De Volkskrant, 27 December 2003.

12 As the latter study was deemed too critical (and therefore endangered the plans) it 'disappeared' for several months. After its existence became known to the Hoogwaterplatform, the group had to invoke the Government Information Act to force the government to make it available.

13 Since the 1990s, the regional development focus has increasingly extended to 'nature development': in contrast to conservation, natural values are designed and engineered into the river landscape in an attempt to 'rewild' the Netherlands.

14 The Zuiderzee was an open and dangerous water body until it was dammed in the early $20^{\text {th }}$ century. It is now known as IJsselmeer (Lake IJssel).

15 http://www.deltaprofessionals.nl/wp-content/uploads/2014/02/Bypass-IJsseldeltapresentatie-Hein-Pijnappel.pdf (accessed 19 June 2018).

16 Waalzinnig is a pun on Dutch 'waanzinnig' (ridiculous); as the river Waal is a branch of the river Rhine, 'Rhinediculous' comes closest to its meaning.

17 Interview with chair and member of citizens' group Waalzinnig, 28 April 2014.

18 A 'sounding board group' (klankbordgroep) is a consultation body, involving stakeholders and experts with no mandate, whose views will be 'taken into account'.

19 Interview with provincial project manager, Arnhem, 6 January 2016.

20 Leaflet "'Bypass Varik-Heesselt", a pre-exploration of the bypass near Varik-Heesselt: jointly running ahead for a decision for more room for the river', 2014.

21 Interview with chair and member of citizen group Waalzinnig, 28 April 2014.

22 'Science Shops are small entities that carry out scientific research in a wide range of disciplines - usually free of charge and on behalf of citizens and local civil society ... A Science Shop provides independent, participatory research support in response to concerns experienced by civil society' (http://www.livingknowledge.org/science-shops/ about-science-shops/ (accessed 26 October 2018). 
23 The present authors were not part of the research team responding to this request, but two authors (Roth and Winnubst) were members of the supervisory team of the study.

24 Dam-like structures in the river, constructed perpendicular to the riverbank, to prevent erosion and check water flows.

\section{References}

Aarden, M. 2003. 'Laat de Ooijpolder niet verzuipen', De Volkskrant, 27 December 2003.

Abma, T. 1999. 'Telling Tales: On Narrative and Evaluation', Advances in Program Evaluation, 6. Arce, A. and N. Long. 2000. Anthropology, Development and Modernities. London: Routledge.

Boezeman, D., M. Vink and P. Leroy. 2013. 'The Dutch Delta Committee as a Boundary Organization', Environmental Science and Policy, 27: 162-171.

Brabants Dagblad. 2014. 'Bypass near Varik Heesselt Remains Promising', Brabants Dagblad, 4 June 2014.

Cleaver, F. 1999. 'Paradoxes of Participation: Questioning Participatory Approaches to Development', Journal of International Development, 11: 597-612.

Commissie Noodoverloopgebieden. 2002. Gecontroleerd Overstromen. Advies van de Commissie Noodoverloopgebieden. The Hague: Projectsecretariaat Commissie Noodoverloopgebieden.

Deltacommissie. 2008. Working Together with Water. A Living Land Builds for its Future. Findings of the Deltacommissie 2008, http://www.deltacommissie.com/doc/deltareport_full.pdf (accessed 26 October 2018).

De Jong, H. and M. Duineveld. 2013. De ruimtelijke ordening als anti-politics-machine. Ruimtevolk. https://ruimtevolk.nl/2013/02/06/de-ruimtelijke-ordening-als-anti-politics-machine/ (accessed 26 October 2010).

De Gelderlander (DG). 2014. '100 Per Cent Safety is Impossible', De Gelderlander, 15 April 2014.

DG 2016a. 'Higher Dike is Already Needed', De Gelderlander, 14 June 2016.

DG. 2016b. 'The Little Bathtub of Varik-Heesselt', De Gelderlander, 4 June 2016.

During, R., M. Pleijte and J.Vreke. 2016. Legitimatie van de nevengeul voor de Waal langs Varik; Constructies van risico's uit onzekerheden die redenen geven voor voorzorg. Achtergrondrapport, rapport 324 deel b, juni 2016. Wageningen UR: Wageningen.

Enserink, B. 2004. 'Thinking the Unthinkable - The End of the Dutch River Dike System? Exploring New Safety Concept for the River Management', Journal of Risk Research, 7(7-8): 745-757.

Ferguson, J. 1990. The Anti-Politics Machine: 'Development', Depoliticization and Bureaucratic Power in Lesotho. Cambridge: Cambridge University Press.

Grijzen, J. 2010. Outsourcing Planning:What do Consultants do in Regional Spatial Planning in the Netherlands. Ph.D. Dissertation. University of Amsterdam.

Harriss, J. 2002. Depoliticizing Development:The World Bank and Social Capital. London: Anthem Press.

HKV Lijn in Water. 2005. Aandachtspunten Bypass Kampen. A report commissioned by Groot Salland Water Board, HKV, Pr1075.10, November 2005, HKV Lijn in Water, Delft.

Kaplan, T.J. 1993. 'Reading Policy Narratives: Beginning, Middles, and Ends', in Fischer, F. and J. Forester (eds). The Argumentative Turn in Analysis and Planning, pp. 167-185. Durham and London: Duke University Press.

Ministry of Infrastructure and the Environment, Programme Directorate Room for the River. 2012a. Room for the River. Safety for Four Million People in the Dutch Delta, http:// www.ruimtevoorderivier.nl/meta-navigatie/english/publications/(accessed 8 April 2014). 
Ministry of Infrastructure and the Environment, Programme Directorate Room for the River. 2012b. Making Room for the Dutch Approach. Corporate Brochure Directorate-General for Public Works and Water Management, http://www.ruimtevoorderivier.nl/media/82838/ factsheet making room for the Dutch approach.pdf. (accessed 26 October 2018).

Ministry of Infrastructure and the Environment, Programme Directorate Room for the River. 2012c. Making Room for Governance, http://www.ruimtevoorderivier.nl/ media/82841/factsheet making room for governance.pdf (accessed 26 October 2018).

Mouffe, C. 2005a. On the Political. Routledge: London.

Mouffe, C. 2005b. The Return of the Political. London:Verso.

Netherlands Environmental Assessment Agency. 2004. Dutch Dikes and Risk Hikes: A Thematic Policy Evaluation of Risks of Flooding in the Netherlands. Extended Summary. National Institute for Public Health and the Environment: Bilthoven, The Netherlands.

Netherlands Environmental Assessment Agency. 2010. Correction Wording Flood Risks for the Netherlands in IPCC Report, http://www.pbl.nl/en/dossiers/Climatechange/content/correction-wording-flood-risks (accessed 26 October 2018).

NRC. 2014. 'That is Quite Something, a River in YourVillage', NRC, 30 August 2014.

Pröpper, I. and D. Steenbeek. 1999. De aanpak van interactief beleid: Elke situatie is anders. Bussum: Coutinho.

Rijke, J., S. van Herk, C. Zevenbergen, and R. Ashley. 2013. 'Room for the River: Delivering Integrated River Basin Management in the Netherlands', International Journal of River Basin Management, 10(4): 369-382.

Roth, D. and J. Warner. 2007. 'Flood risk, Uncertainty and Changing River Protection Policy in the Netherlands:The Case of "Calamity Polders", Tijdschrift voor Economische en Sociale Geografie, 98(4): 519-525.

Roth, D. and J. Warner. 2009. 'Rural Solutions for Threats to Urban Areas: The Contest over Calamity Polders', Built Environment, 35(4): 545-562.

RT Oost. 2016. 'A Place for a Maximum of 600 Houses in Plan Reeve near Kampen', RT Oost, 15 December 2016.

Satink, M. 2015. 'De IJsselstad, de hoogwatergeul en het gewraakte dorp', Reformatorisch Dagblad, 12 February 2015.

Shore, C., S. Wright and D. Però (eds). 2011. Policy Worlds: Anthropology and the Analysis of Contemporary Power. New York: Berghahn Books.

Sligter, A. 2009. 'Bypass Construction at Kampen Dangerous', De Volkskrant, 29 March 2009.

Te Linde, A.H., J.C.J.H. Aerts and J.C.J. Kwadijk. 2010. 'Effectiveness of Flood Management Measures on Peak Discharges in the Rhine Basin under Climate Change', Journal of Flood Risk Management, 3: 248-269.

ten Heuvelhof, E., H. de Bruijn, M. de Wal, M. de Kort, M. vanVliet, M. Noordink, and M.Böhm. 2007. Procesevaluatie Totstandkoming PKB Ruimte voor de Rivier. Utrecht: Berenschot.

Toonen, T.A.J., G.S.A. Dijkstra and F. van der Meer. 2006. 'Modernization and Reform of Dutch Waterboards: Resilience or Change?', Journal of Institutional Economics, 2(2):181-201. van Buuren, A. and J. Warner. 2014. 'From Bypass to Bathtub: Backfiring Policy Labels in Dutch Water Governance', Environment and Planning C: Government and Policy, 32: 1000-1016.

van Buuren, A. and J. Warner. 2010. 'Klimaatverandering en waterveiligheid, tussen ernst en enthousiasme. De discursieve framing van bedreigingen en kansen', $B E M, 37(1)$ : 14-28.

van Drimmelen, L. and M. van Buuren. 2004. Ruimte voor de Rivier als cultuurhistorie van de toekomst. Zoektocht naar de aard van een ontwerpopgave. Landschap, 21(1): 55-64, http:// www.landschap.nl/wp-content/uploads/2004-1_55-64.pdf (accessed 26 October 2018). 
van Heezik, A. 2008. Battle Over the Rivers: Two Hundred Years of River Policy in the Netherlands. Ministry of Transport, Public Works and Water Management, The Hague.

van Stokkom, H., A. Smits and R. Leuven. 2005. 'Flood Defense in the Netherlands: A New Era, a New Approach', Water International, 30: 76-87.

Vink, M.J., D. Boezeman, A. Dewulf and C.J.A.M. Termeer. 2013. 'Changing Climate, Changing Frames: Dutch Water Policy Frame Developments in the Context of a Rise and Fall of Attention to Climate Change', Environmental Science and Policy, 30: 90-101.

Warner, J., J. Edelenbos and A. van Buuren. 2013a. 'Making Space for the River: Governance Challenges', in J. Warner, A. van Buuren and J. Edelenbos (eds), Making Space for the River. Governance Experiences with Multifunctional River Flood Management in the US and Europe, pp. 1-13. London: IWA Publishing.

Warner, J. and A. van Buuren. 2011. 'Implementing Room for the River: Narratives of Success and Failure in Kampen, the Netherlands', International Review of Administrative Sciences, 77(4): 779-801.

Warner,J.F.,A. van Buuren and J. Edelenbos (eds). 2013b. Making Space for the river. Governance experiences with Multifunctional River Flood Management in the US and Europe. London: IWA Publishing.

Wiering, M.A. and B.J.M. Arts. 2006. 'Discursive Shifts in Dutch River Management:"Deep" Institutional Change or Adaptation Strategy?', Hydrobiologia, 56(5): 327-338.

Wiering, M.A. and P.P.J. Driessen. 2001. 'Beyond the Art of Diking: Interactive Policy on River Management in The Netherlands', Water Policy, 3: 283-296.

Wiering, M. and I. Immink. 2006. 'When Water Management Meets Spatial Planning: A Policy Arrangements Perspective', Environment and Planning C, 24: 423-438.

Wolsink, M. 2006. 'River Basin Approach and Integrated Water Management: Governance Pitfalls for the Dutch Space-Water-Adjustment Management Principle', Geoforum, 37: 473-487.

Wolsink, M. 2010.'Contested Environmental Policy Infrastructure: Socio-Political Acceptance of Renewable Energy, Water, and Waste Facilities', Environmental Impact Assessment Review, 30: 302-303. 